\title{
Prologue
}

\section{A Savvy Political Operative: Czechs Thought He Was Russian, and Russians Thought He Was Czech}

Steve Thomas was my beloved husband. Nobody has ever found a more compatible husband. We were together since we were eighteen and in our junior year at Harvard. We met when he came to our house with my brother. For the rest of his life he remembered the dress I was wearing when he saw me coming down the stairs, and I still remember the jeans and yellow shirt he wore when, moments later, I saw him.

Many years later, long after we were married, a nice man who was studying the reactions of people to the college they attended came to question us. I said, "Harvard was sort of okay, I guess, although I didn't learn much," but Steve was very enthusiastic. He loved the classes he had taken and he learned an amazing amount. The nice man told us that colleges like Princeton were usually seen with Steve's enthusiasm while colleges like Harvard were not. Why? Because the Princeton professors knew their students, liked them, and guided them while the Harvard professors just entered the classrooms, gave their lectures, and walked out. But Steve loved to learn. He didn't care if the professors knew him and he didn't need their help. Harvard offered a wide array of subjects and Steve consumed as many as he could.

Steve was especially interested in languages. He soon learned French and German, and then moved from his dormitory to the home of a Russian couple where he soon was speaking fluent Russian. During that time, he and I took a course in Spanish together. When the class was over I left with no more than entiendo nada, but he left speaking fluently. By the time he was in his thirties he spoke German, French, Spanish, Russian, Czech, Italian, English of course, and also some Yoruba and Korean. He didn't count Yoruba or Korean because he didn't think he "spoke” a language until he was fluent. I spoke only English but even in English he knew more words than I did. He knew what onomatopoeia meant, for instance. What does it mean? Don't look at me.

When we graduated from Harvard he was drafted and stationed at Fort Bragg, North Carolina, in a unit of soldiers chosen for the languages they spoke. All but Steve were from other countries. The Army, of course, deals with other languages constantly and this unit was their source of expertise. Steve's memory of the experience was writing notes in Korean for planes to drop on Korea, or in other words, it wasn't too exciting. 
We got married and, when he was discharged, we moved to New York City where I got a job and he went to graduate school at Columbia University to study the history of Central Europe. That program didn't offer a PhD, just a paper saying you had taken the courses, but he wasn't interested in degrees-all he wanted was to learn about Central Europe. Which he did.

He was equally interested in politics. After Columbia, he worked for a company that focused on electing senators who were opposed to atomic warfare. He would visit the states where the candidates lived, learn what the general public was thinking, decide whether or not the candidate had what it took to win, and whether or not to support that candidate. At one time, literally half the senators in Congress had been put there thanks to Steve's investigations and help. One of those senators is now President Joe Biden. I met him many years later when he was running for President and gave a talk in the little New Hampshire town where Steve and I had settled. Steve was no longer living but Biden remembered him with much affection. Without Steve's help, said President Biden, he would not have been elected to the Senate.

When Steve was in his late fifties, he left this interesting job to pursue his other passion-the history of what had been Czechoslovakia and became, in part, the Czech Republic. In 1989 after the Iron Curtain was lifted, non-communists were allowed to visit the archives, of which there were many, so that is what he did. By then he spoke Czech quite perfectly. Czechs really did think he was a Russian and the Russians believed he was a Czech. He would spend three months in the Czech Republic, which after World War II had reacquired the German area of Sudetenland, then three months at home, then again three months in the Czech Republic, a plan which he kept for perhaps fifteen years. He liked to be thorough.

Did I object to his long absences? Well, I missed him, of course, but I wanted him to be happy. Also, I could visit him so I often did, and he hadn't objected when, before all this, I had taken our two little kids to northern Uganda so I could write a book about the Dodoth warriors, or when I left the little kids with him so I could spend a summer alone beside a den of wolves on Baffin Island and include wolves in a book I was writing about the dog family. So there we were. I wrote several books, including the dog book, and he wrote this book, a step-by-step account of the Czech v. Czech and Czech v. German struggles, including all the participants and all the results-the only book that I know of that begins to demonstrate what really happened. If my books are like molehills, his is like a mountain. 
Steve died in 2015 of ALS, that's amyotrophic lateral sclerosis-not a good disease to have and always fatal-with his loving family beside him. He left us this book.

Elizabeth Marshall Thomas

Peterborough NH, USA

April 12, 2021 
